\title{
DETERMINAN CASH HOLDING BANK YANG TERDAFTAR DI BURSA EFEK INDONESIA
}

\author{
Umi Murtini \\ Mathew Julius Ukru \\ Fakultas Bisnis Universitas Kristen Duta Wacana \\ Email korespondensi: umimt@staff.ukdw.ac.id
}

\begin{abstract}
ABSTRAK
Penelitian ini bertujuan untuk menguji pengaruh arus kas, modal kerja bersih, leverage, dan pembayaran dividen terhadap cash holding pada perusahaan bank yang terdaftar di Bursa Efek Indonesia tahun 2015-2019. Pengambilan sampel dilakukan dengan teknik purposive sampling. Jenis penelitian ini adalah penelitian asosiatif dengan pendekatan kuantitatif, analisis data yang digunakan adalah uji asumsi klasik dan regresi linier berganda. Hasil penelitian ini menunjukkan bahwa Leverage berpengaruh signifikan terhadap cash holding dengan nilai signifikan sebesar 0,0366. Sedangkan variabel arus kas, modal kerja bersih, dan pembayaran dividen tidak berpengaruh signifikan terhadap kepemilikan kas.
\end{abstract}

Kata kunci: cash holding, arus kas, modal kerja bersih, pembayaran dividen

\begin{abstract}
This research aims to examine the effect of cash flow, net working capital, leverage, and dividend payment on cash holding of bank companies listed on the Indonesia Stock Exchange in 2015-2019. Sampling was done using purposive sampling technique. The type of research is associative research with a quantitative approach, the data analysis used is the classical assumption test and multiple linear regression. The results of this study indicate that leverage has a significant effect on Cash Holding with a significant value of 0.0366. Meanwhile, the variables of cash flow, net working capital, and dividend payment have no significant effect on cash holding.
\end{abstract}

Keywords: cash holding, cash flow, net working capital, dividend payment 


\section{PENDAHULUAN}

Kas berperan penting dalam pembiayaan kegiatan operasional dan menunjukkan likuiditas perusahaan. Gill dan Shah (2012) menyatakan bahwa keputusan perusahaan dalam menahan kas secara langsung berkaitan dengan keputusan investasi perusahaan, hal ini tergantung pada fleksibilitas keuangan. Perusahaan yang mengantisipasi kendala keuangan di masa depan akan lebih konservatif dan menahan kas pada saat ini untuk meminimalisasi kemungkinan dampak buruk di masa depan (Kim et al., 1998). Kas sebagai aset untuk memanfaatkan peluang di masa depan. Kas digunakan untuk memanfaatkan kesempatan investasi perusahaan, baik berupa investasi fisik maupun keuangan.

Teori trade-off menyatakan biaya memegang kas adalah opportunity cost dari modal yang di investasikan dalam aset likuid. Manfaat memegang kas yaitu mengurangi eksposur financial distress, memperlonggar kebijakan investasi, dan meminimumkan biaya untuk tambahan dana eksternal atau melikuidasi aset (Ferreira dan Vilela, 2004). Teori pecking order, menyatakan urutan sumber pendanaan perusahaan yaitu dana internal yang berasal dari laba ditahan, pendanaan eksternal, dan ekuitas. Teori agency menunjukkan bahwa manajer perusahaan dengan peluang investasi yang buruk cenderung mempertahankan kas yang besar, teori ini memungkinkan terjadinya masalah yang disebut sebagai conflict of interest yang biasanya terjadi saat mengambil keputusan.

Sigit dan Totok (2006), bank merupakan salah satu lembaga keuangan yang menghimpun dan menyalurkan dana. Bank sebagai perusahaan yang menyediakan layanan keuangan dalam hal ini juga perlu menjaga likuiditas dan memperhatikan kebutuhan dana untuk aktivitas operasionalnya. Agar bank mendapat keuntungan maka dana yang dialokasikan di aset produktif mampu memberikan pendapatan bagi bank. Apabila jumlah dana yang dialokasikan terlalu besar, maka likuiditas perusahaan dapat terganggu. Bank memiliki karakter berhatihati dalam menjaga likuiditasnya, cenderung menyimpan kas relatif besar untuk menghindari risiko kesulitan likuiditas. Hal ini menjadi alasan penulis memilih bank sebagai objek penelitian.

\section{TELAAH LITERATUR DAN PENGEMBANGAN HIPOTESIS Kas}

Martani (2012) kas merupakan aset keuangan yang likuid dan digunakan untuk kegiatan operasional perusahaan dan membayar kewajiban perusahaan. Kas pada umumnya terdiri atas mata uang dan giro atau demand deposit (Kieso, et al., 2008). Perusahaan perlu menjaga keseimbangan kas optimal. Semakin besar kas maka likuiditas semakin tinggi sehingga risiko kewajiban finansial semakin kecil. Apabila kas sangat besar, maka ada kemungkinan dana menganggur dan perusahaan kehilangan kesempatan memperoleh laba yang lebih besar.

\section{Teori Cash Holding}

Gill dan Shah (2012), cash holding diartikan sebagai kas yang ada di tangan atau tersedia untuk diinvestasikan dalam bentuk aset fisik dan untuk dibagikan ke investor. Menurut Ross et al. (2012), terdapat tiga motif dari cash holding, yaitu motif transaksi, motif berjaga-jaga, dan motif spekulasi. Keynes (1936) menetapkan tiga motif untuk cash holding yakni, perusahaan menahan kepemilikan kas untuk motif transaksi, precaution terhadap biaya yang tidak diharapkan, dan untuk tujuan spekulatif.

Motif transaksi, perusahaan menyediakan kas untuk memenuhi operasi perusahaan. Jika perusahaan mudah mendapatkan dana dari pasar modal, maka perusahaan kemungkinan besar tidak memerlukan cash holding dalam jumalah besar. Keuntungan cash holding adalah perusahaan mampu menurunkan transaction cost dengan menggunakan kas daripada melikuidasi aset. 
Motif berjaga-jaga menyatakan, kas digunakan untuk mengantisipasi peristiwa yang tidak terduga dari aspek pembiayaan. Perusahaan diharapkan untuk memegang kas sebagai tindakan pencegahan untuk melindungi kekurangan kas di masa depan.

Motif spekulasi menyatakan bahwa perusahaan akan berspekulasi dan mengamati berbagai peluang bisnis baru yang diyakini dapat memberi keuntungan bagi perusahaan dengan menggunakan kas yang dimiliki. Husnan \& Pudjiastuti (2006) menyatakan bahwa motif berjaga-jaga dimaksudkan untuk mempertahankan saldo kas guna memenuhi permintaan kas yang sifatnya tidak terduga. Bila pengeluaran dan pemasukan kas dapat diprediksi dengan baik oleh perusahaan, maka saldo kas yang disiapkan untuk berjaga-jaga akan lebih rendah. Hal tersebut berlaku juga apabila perusahaan memiliki akses yang kuat terhadap sumber dana eksternal.

\section{Teori Agensi}

Teori keagenan tidak hanya dinilai sebagai hubungan antara pemilik sumber daya dengan pemberi dana. Teori agensi mengasumsikan bahwa setiap pihak melakukan tindakannya untuk kepentingan sendiri. Manajer pada perusahaan dengan peluang investasi yang buruk cenderung untuk mempertahankan kas daripada melakukan pembayaran.

\section{Cash Flow}

Rahmawati (2013), besar kecilnya kas yang dimiliki tergantung pada cash flow perusahaan. Cash flow bersih positif membuat perusahaan tidak bergantung dengan pihak eksternal. Berdasarkan teori trade-off, cash holding sedikit karena arus kas digunakan perusahaan untuk membiayai kegiatan operasional sehingga mengurangi kas. Artinya bila cash flow tinggi, maka cash holding sedikit.

Syaifuddin (2008), working capital merupakan jumlah seluruh dana yang tertanam dalam aktiva lancar perusahaan dimaksudkan sebagai aktiva yang dapat berubah menjadi kas secara normal dalam jangka waktu yang relatif pendek. Ross et al. (2015), net working capital adalah aset lancar dan kewajiban lancar yang dapat menghasilkan modal kerja yang positif saat aset lancar lebih besar dari kewajiban lancar. Gitman dan Zutter (2015) bila perusahaan memiliki modal kerja dalam jumlah besar, maka jumlah kas yang dimiliki perusahaan juga akan semakin besar, karena jumlah aset yang dimiliki perusahaan melebihi hutang perusahaan.

\section{Leverage}

Hery (2015), Sartono (2012), Ali, Ullah \& Ullah (2016) mengungkapkan bahwa leverage adalah kondisi dimana perusahaan membeli asetnya secara kredit dengan meyakini bahwa laba yang dihasilkan dari aset tersebut akan lebih besar jika dibandingkan dengan pinjaman yang diterima untuk membeli aset tersebut. Ferreira dan Vilela (2004), tingkat leverage perusahaan tinggi, maka perusahaan dapat diprediksikan memiliki uang tunai yang banyak karena default risk yang tinggi. Penyebab perusahaan memiliki leverage yang tinggi salah satunya adalah karena adanya pembiayaan aset dengan menggunakan hutang perusahaan. Oleh karena itu, bila hutang perusahaan lebih besar dibandingkan dengan total aset yang dimiliki perusahaan, maka leverage perusahaan akan semakin tinggi.

\section{Dividend Payment}

Titman, Keown, dan Martin (2014) mengatakan bahwa pembayaran kepada pemegang saham dapat dilakukan dalam bentuk dividen kas dan pembelian kembali saham. Mengacu pada teori trade off, perusahaan dengan arus kas yang cukup akan melakukan pembayaran dividen atau melakukan pembelian kembali saham agar perusahaan memiliki aset likuid yang rendah. Perusahaan yang membayarkan dividen akan memiliki akses yang lebih mudah dalam menghimpun dana melalui pendanaan eksternal. Maka perusahaan tidak perlu memegang kas untuk motif precautionary (Opler et al., 2009). Teori 
pecking order juga menyatakan bahwa perusahaan akan memegang kas lebih kecil bila perusahaan melakukan pembayaran dividen. Ozkan dan Ozkan (2004) mengungkapkan bahwa ada kemungkinan bagi perusahaan yang membayarkan dividen untuk memegang kas dalam jumlah besar untuk menghindari kekurangan kas setelah melakukan pembayaran dividen.

\section{Penelitian Terdahulu}

Koo \& Maeng (2018), menemukan bahwa ukuran perusahaan, volatilitas penjualan dan arus kas, dan struktur tata kelola tidak mempengaruhi sensitivitas arus kas dari kepemilikan kas. Peluang investasi ditemukan mempengaruhi sensitivitas kepemilikan kas dalam menanggapi peningkatan arus kas.

Suherman (2017), menbuktikan bahwa net working capital dan sales growth berpengaruh positif, sedangkan firm size berpengaruh negatif terhadap cash holding. Cash flow, cash flow variability, cash conversion cycle, liquidity, dan leverage tidak berpengaruh terhadap cash holdings.

Bates, Kahle dan Stultz (2009), menemukan capital expenditure, firm size, leverage, dividend payout ratio, net working capital berpengaruh negatif sedang industry cash flow risk, $R \& D$ to sales dan investment opportunities berpengaruh positif terhadap cash holding.

Ferreira dan Vilela (2004) menemukan leverage, liquidity assets subtitutes dan size berpengaruh negatif, sedang profitability dan investment opportunity set berpengaruh positif terhadap cash. May Daher (2010), menemukan investment opportunities, firm size, profitability, liquid assets substitutes dan capital expenditure berpengaruh negatif terhadap cash.

\section{Hipotesis}

Ferreira dan Vilela (2004), Afza dan Adnan (2007), Prasentianto (2014), dan Ogundipe et al. (2012) yang menunjukkan bahwa cash flow berpengaruh negatif terhadap cash holding. Sehingga hipotesis disusun sebagai berikut:
$\mathrm{H}_{1}$ : Cash flow berpengaruh negatif terhadap cash holding.

Berdasar pada teori trade-off, net working capital memiliki hubungan negatif terhadap cash holding. Bates et al. (2009) mengungkapkan bahwa net working capital bisa digunakan sebagai substitusi kas perusahaan. Ferreira dan Vilela (2004), net working capital merupakan pengganti uang tunai karena pada saat dibutuhkan, net working capital dapat dengan cepat dilikuidasi untuk pendanaan. Sehingga, perusahaan dengan net working capital yang banyak cenderung memegang kas dalam jumlah yang sedikit. Penelitian Ferreira dan Vilela (2004), D’Mello (2005), Bates (2009), Kim et al. (2011), dan Ogundipe et al. (2012) mengungkapkan net working capital berpengaruh negatif pada cash holding. Sehingga hipotesis dapat disusun sebagai berikut:

$\mathrm{H}_{2}$ : Net working capital berpengaruh negatif terhadap cash holding.

Fahmi (2013) menyatakan bahwa leverage merupakan alat untuk mengukur seberapa besar perusahaan tergantung pada kreditur dalam membiayai aset perusahaan. Artinya leverage digunakan untuk menghitung seberapa besar perusahaan dibiayai oleh hutang. Penelitian yang dilakukan oleh Musarat dan Ullah (2015) serta Thu dan Khuong (2018) menyatakan bahwa leverage berpengaruh negatif terhadap cash holding. Namun hal tersebut berbeda dengan hasil penelitian yang dilakukan oleh Selcuk \& Yilmaz (2017) yang menunjukkan hasil bahwa leverage berpengaruh positif terhadap cash holding. $\mathrm{H}_{3}$ : Leverage berpengaruh positif terhadap cash holding.

Dividen merupakan pembagian keuntungan yang diberikan perusahaan dan berasal dari keuntungan yang dihasilkan perusahaan. Perusahaan yang membayar dividen akan membuat cadangan kas guna menjaga likuiditas perusahaannya. Ozkan dan Ozkan (2004) mengungkapkan bahwa ada kemungkinan bagi perusahaan yang 
membayarkan dividen untuk memegang kas dalam jumlah besar untuk menghindari kekurangan kas setelah melakukan pembayaran dividen. Penelitian yang dilakukan oleh Jinkar (2012) mengungkapkan bahwa dividend payment berpengaruh positif terhadap cash holding. Sehingga hipotesis dapat disusun sebagai berikut:

$\mathrm{H}_{4}$ : Dividend payment berpengaruh positif terhadap cash holding.

\section{METODE PENELITIAN}

\section{Populasi dan Metode Sampling}

Populasi penelitian ini adalah semua perusahaan yang terdaftar di BEI. Pemilihan sampel dilakukan dengan purposive sampling dengan kriteria: perusahaan perbankan yang selalu listing di BEI mulai tahun 2015 sampai 2019 dan memiliki data yang digunakan penelitian secara lengkap. Berdasar kriteria tersebut diperoleh 42 perusahaan. Data yang digunakan data sekunder yang berasal dari idx.co.id dan dikumpulkan dengan dokumentasi.

\section{Definisi Variabel dan Pengukurannya}

Variabel dependen yang digunakan dalam penelitian ini adalah variabel cash holding. Rumus untuk menghitung cash holding yang dilakukan oleh Marfuah dan Zulhilmi (2014), Ogundipe et al. (2012), Teruel et al. (2009) yaitu:

Cash holding $=$ (kas dan setara kas)/(total aset)

\section{Variabel Independen}

\section{Cash Flow}

Cash flow merupakan suatu laporan yang memuat informasi mengenai jumlah uang kas yang keluar dan yang masuk perusahaan untuk memenuhi kegiatan operasional perusahaan pada periode waktu tertentu. Rumus mengukur cash flow menurut Ferreira dan Vilela (2004) adalah sebagai berikut:

Cash flow = (laba setelah pajak+depresiasi)/(total aset)

\section{Net Working Capital}

Modal kerja bersih merupakan selisih antara aset lancar dengan kewajiban lancar dibagi dengan total aset. Penghitungan modal kerja bersih (Jinkar, 2013):

Net Working Capital= (aset lancar-hutang lancar)/(total aset)

\section{Leverage}

Leverage merupakan kebijakan perusahaan tentang seberapa jauh perusahaan menggunakan pendanaan di luar perusahaan. Pengukuran tingkat leverage (Keown et al. 2011):

Leverage $=($ total hutang $) /($ total aset $)$

\section{Dividend Payment}

Dividen merupakan pembagian keuntungan yang diberikan perusahaan dan berasal dari keuntungan yang dihasilkan perusahaan. Pengukuran dividend payment yang dilakukan pada penelitian Al-Najjar (2013) dihitung menggunakan :

Dividend Payment=(Dividend per share)/(Earning per share)

\section{Pengujian Hipotesis}

Hipotesis diuji menggunakan regresi berganda dengan data panel. Persamaan regresi digunakan:

Cash Holding $=\alpha+\beta_{1}$ Cash Flow $+\beta_{2}$ Net Working Capital $+\beta_{3}$ Leverage $+\beta_{4}$ Dividend Payment $+\varepsilon$

\section{HASIL PENELITIAN DAN PEMBAHASAN}

\section{Gambaran Data}

Penelitian ini menggunakan obyek perusahaan perbankan yang listing di BEI th 2015 - 2019. Jumlah perusahaan yang memenuhi kriteria sampling ada 42 perusahaan. Gambaran data penelitian dapat dilihat dalam Tabel 1 di bawah ini: 
Tabel 1. Statistik Deskriptif

\begin{tabular}{lccllc}
\hline \multicolumn{1}{c}{ Keterangan } & CH & CF & NWC & LEV & DPR \\
\hline Mean & 0.183426 & 0.013493 & 0.418313 & 0.801625 & 0.139118 \\
Maximum & 0.583660 & 0.078460 & 0.788170 & 0.977590 & 0.951850 \\
Minimum & 0.050510 & -0.112290 & 0.084300 & 0.052420 & -0.042070 \\
Observations & 210 & 210 & 210 & 210 & 210 \\
\hline
\end{tabular}

Sumber: Data diolah

Dalam Tabel 1 terlihat jumlah observasi 210, berdasar dari perioda penelitian 5 tahun untuk 42 perusahaan. Cash holding $(\mathrm{CH})$ minimal jumlah kas dan setara kas perusahaan perbankan sebesar $5 \%$ dari total asetnya dan maksimum jumlah kas 58\% dari total aset. Kas lebih dari $50 \%$ berarti bahwa sebagian besar struktur aset perbankan didominasi dengan kas, sedang aset tetapnya lebih kecil dari kas. Hal ini dimungkinkan karena bisnis utama bank adalah menyalurkan kredit (kas) pada nasabah.

Cash flow minimal nilainya negatif, menunjukkan bahwa ada perusahaan perbankan yang memiliki cash outflow lebih besar dibanding cash inflownya. Ratarata perusahaan perbankan memiliki cash flow positif, sehingga memiliki cash inflow yang lebih besar dibanding cash outflownya.

Nilai kas bersih maksimum 78\%, hal ini menunjukkan bahwa jumlah kas bersih sebesar $78 \%$ dari total aset. Karena ini perusahaan perbankan maka sangat baik bila sebagian besar asset perusahaan ini berupa modal kerja bersih. Rata-rata perusahaan perbankan yang menjadi obyek penelitian merupakan perusahaan yang likuid. Hal ini mendukung usaha perbankan yaitu menyalurkan dana (kas) kepada masyarakat. Olehkarena itu bank harus menyediakan jumlah kas bersih yang cukup tinggi. Ini juga untuk kesehatan bank.

Variabel Leverage (LEV) maksimum 97,78\%, hal ini menunjukkan bahwa jumlah hutang 97,78\% dari total asetnya. Karena pendanaan sebagian besar dari hutang melalui deposito dan tabungan dari masyarakat. Hutang yang besar ini juga menunjukkan bahwa ekuitas perusahaan sangat kecil. Perbankan adalah perusahaan yang mengumpulkan dana dari masyarakat dan menyalurkan kembali kepada masyarakat.

Variabel Dividend Payment (DPR) sebesar 0,139118. Hal ini menunjukkan bahwa perusahaan membagikan deviden sebesar 13,91\% dari keuntungan yang didapatkan. Hal ini menunjukkan bahwa sebagian besar dari keuntungan ditahan untuk perluasan usaha.

\section{Analisis}

Pemilihan model dengan menggunakan Chow Test, Hausman Test, dan Lagrange Multiplier Test diperoleh model yang paling tepat adalah random. Model random yang telah lolos dari uji asumsi klasik adalah dengan melakukan logaritma. Hasil regresi dapat dilihat dalam Tabel 2 di bawah ini:

Tabel 2. Hasil Regresi dengan Random (logaritma)

\begin{tabular}{lcc}
\hline \multicolumn{1}{c}{ Variabel } & Coefisien & t-Statistic \\
\hline Cash Flow & $-1,328710$ & $-3,908432^{* * *}$ \\
Modal Kerja Bersih & $-0,193401$ & $-2,850031^{* * *}$ \\
Leverage & 0,821090 & $2,190032^{* *}$ \\
Devidend Pay Out Ratio & 0,400972 & $5,398061^{* * *}$ \\
\hline
\end{tabular}


Dari Tabel 2 di atas terlihat bahwa cash flow berpengaruh negatif terhadap cash holding. Hal ini berarti bahwa semakin besar cash flow maka cash holding perusahaan semakin kecil.

Cash flow positif menunjukkan bahwa cash inflow lebih besar dibandingkan cash outflow. Sesuai dengan teori trade-off, kas digunakan untuk membiayai operasi perusahaan. Dengan demikian bila ada cash holding yang besar perusahaan tidak bergantung dengan dana dari luar. Penelitian ini mendukung penelitian Ferreira dan Vilela (2004), Afza dan Adnan (2007), Prasentianto (2014), dan Ogundipe et al. (2012) yang menunjukkan bahwa cash flow berpengaruh negatif terhadap cash holding.

Modal kerja bersih berpengaruh negatif terhadap cash holding. Semakin besar modal kerja bersih, maka semakin kecil cash holdingnya. Menurut Ferreira dan Vilela (2004), net working capital merupakan pengganti uang tunai karena pada saat dibutuhkan, net working capital dapat dengan cepat dilikuidasi untuk pendanaan. Penelitian ini mendukung penelitian Ferreira dan Vilela (2004), D’Mello (2005), Bates (2009), Kim et al. (2011), dan Ogundipe et al. (2012) mengungkapkan net working capital berpengaruh negatif pada cash holding.

Leverage berpengaruh positif terhadap cash holding. Semakin tinggi penggunaan hutang sebagai sumber pendanaan, maka cash holding perusahaan semakin besar. Hasil ini mendukung penelitian Selcuk \& Yilmaz (2017) yang menunjukkan hasil bahwa leverage berpengaruh positif terhadap cash holding. Tingkat leverage perusahaan yang sangat tinggi mengharuskan perusahaan untuk memiliki uang tunai yang banyak karena default risk yang tinggi.

Dividend payment berpengaruh positif terhadap cash holding. Dividen adalah pembagian keuntungan yang diberikan perusahaan dan berasal dari keuntungan yang dihasilkan perusahaan.
Penelitian ini mendukung penelitian Jinkar (2012) yang mengungkapkan bahwa dividend payment berpengaruh signifikan positif terhadap cash holding.

\section{KESIMPULAN, KETERBATASAN, DAN SARAN \\ Kesimpulan}

Berdasarkan analisis di atas, maka disimpulkan cash flow dan modal kerja bersih berpengaruh negatif terhadap cash flow. Sedangkan leverage dan devident pay out berpengaruh positif terhadap cash flow.

\section{Keterbatasan}

Keterbatasan penelitian ini nilai aktiva lancar yang ada di dalam rumus variabel net working capital belum menghilangkan kas dan setara kas dimana kas dan setara kas juga muncul pada variabel cash holding.

\section{Saran}

Bagi peneliti berikutnya disarankan untuk penghitungan modal kerja bersih tidak memasukkan kas dan setara kas. Karena kas dan setara kas juga digunakan dalam perhitungan cash holding.

\section{REFERENSI}

Afif, S., \& Prasetiono. (2016). Analisis Faktor-Faktor Yang Mempengaruhi Kebijakan Cash Holding Pada Perusahaan Manufaktur Yang Listing Di Bursa Efek Indonesia Tahun 20102014. Diponegoro Journal of Management, Vol. 5.

Daher, M. (2010). The Determinants of Cash Holdings in UK Public and Private Firms. Dissertation.

Fauzi, S. (2013). Analisis Pengaruh Growth Opportunity, Net Working Capital, dan Cash Conversion Cycle terhadap Cash Holding Perusahaan Sektor Pertambangan. Jurnal Ekonomi dan Keuangan, 1.

Ferreira, M., \& Vilela, A. (2004). Why Do Firms Hold Cash? Evidence from EMU Countries. European Financial Management, 10. 
JRMB, Volume 16, No. 1, Juni 2021

Gill, A., \& Shah, C. (2012). Determinants of corporate cash holdings: Evidence from Canada. International Journal of Economics and Finance.

Jinkar, R. T. (2012). Analisa Faktor-Faktor Penentu Kebijakan Cash Holdings. Mini Economica. Edisi 42.

Kim, C. S., Mauer, D., \& Sherman, A. E. (1998). The Determinants of Corporate Liquidity: Theory and Eidence. Journal of Financial and Quantitative Analysis.

L, Z. E., \& Susanto, L. (2020). Pengaruh Leverage, Firm Size, Likuiditas, dan Profitabilitas Terhadap Cash Holding. Jurnal Multiparadigma Akuntansi Tarumanagara, Vol. 2.

Liestyasih, L. P., \& Wiagustini, L. P. (2017). Pengaruh Firm Size dan Growth Opportunity Terhadap Cash Holding dan Firm Value. E-Jurnal Ekonomi dan Bisnis Universitas Udayana.

Margaretha, I., \& Dewi, S. P. (2020). Faktor-Faktor Yang Mempengaruhi Cash Holding Pada Perusahaan Manufaktur. Jurnal Multiparadigma Akuntansi Tarumanagara, Vol. 2.

Mawarti, H., Chomsatu, Y., \& Siddi, P. (2020). Faktor-Faktor yang Mempengaruhi Cash Holding pada Perusahaan Manufaktur yang Terdaftar fi Bursa Efek Indonesia. Tirtayasa Ekonomika, Vol. 15.

Najema, \& Asma, R. (2019). Analisis Pengaruh Current Asset, Capital Expenditure, Cash Conversion Cycle, Cash Flow, Leverage, Market to Book Value dan Net Working Capital Terhadap Cash Holdings pada Sektor Industri Barang Konsumsi di BEI. Jurnal Sains Manajemen dan Kewirausahaan, Vol. 3.

Ozkan, A., \& Ozkan, N. (2004). Corporate Cash Holdings: An Empirical Investigation of UK Companies. Journal of Banking \& Finance, Vol. 28.

Pasaribu, G. S., \& Nuringsih, K. (2019). Faktor Yang Mempengaruhi Cash Holding Perusahaan Manufaktur
Yang Terdaftar Di BEI. Jurnal Manajerial dan Kewirausahaan, Vol. 1.

Suherman. (2017). Faktor-Faktor yang Mempengaruhi Cash Holdings Perusahaan di Bursa Efek Indonesia. Jurnal Manajemen, Vol. 21. 